\title{
Paradigma Baru Pelaksanaan Investasi Pemerintah Pusat Dalam Perspektif Hukum Keuangan Negara
}

\author{
Gerry M.T \\ Magister Ilmu Hukum, Universitas Indonesia \\ Email: gerry.mt@ui.ac.id
}

\begin{abstract}
Government investment as one of the instruments of the central government in relation to the management of state finances began to be publicly introduced with the issuance of Law Number 1 of 2004 concerning State Treasury. Government investment is carried out to obtain economic benefits, social benefits and other benefits for the implementation of national development aimed at achieving social welfare for all Indonesian people as mandated in the 1945 Constitution of the Republic of Indonesia. Government investment is not only one of the tools. in national development, but moreover it becomes the main instrument in running the economy of the Indonesian nation considering that the implementation of government investment is carried out in various forms of investment instruments in the form of stocks, debt securities and / or direct investment whose financing is allocated in the State Revenue and Expenditure Budget. This journal explains the implementation of government investment carried out by the Minister of Finance as the current State General Treasurer based on existing laws and regulations in the perspective of state financial law.
\end{abstract}

Keywords: State Finance Law, Government Investment, State Revenue And Expenditure Budget, State General Treasurer.

Abstrak. Investasi pemerintah sebagai salah satu instrumen Pemerintah pusat dalam kaitannya dengan pengelolaan keuangan negara mulai di perkenalkan secara terbuka dengan diterbitkannya Undang-Undang Nomor 1 Tahun 2004 tentang Perbendaharaan Negara. Investasi pemerintah dilaksanakan untuk memperoleh manfaat ekonomi, manfaat sosial dan manfaat lainnya demi terselenggaranya pembangunan nasional yang bertujuan untuk tercapainya kesejahteraaan sosial bagi seluruh rakyat Indonesia sebagaimana diamanatkan dalam Undang-Undang Dasar Negara Republik Indonesia Tahun 1945. Investasi pemerintah saat ini bukan hanya menjadi salah satu tools dalam pembangunan nasional namun terlebih lagi menjadi instrument utama dalam menjalankan roda perekonomian bangsa Indonesia mengingat pelaksanaan investasi pemerintah tersebut dilakukan dalam berbagai bentuk instrument investasi berupa saham, surat utang dan/atau investasi langsung yang pembiayaannya dialokasikan dalam Anggaran Pendapatan dan Belanja Negara. Jurnal ini menjelaskan mengenai pelaksanaan investasi pemerintah yang dilakukan oleh Menteri Keuangan selaku Bendahara Umum Negara saat ini dengan mendasarkan peraturan perundang-undangan yang ada dalam perspektif hukum keuangan negara.

Kata Kunci: Hukum Keuangan Negara, Investasi Pemerintah, Anggaran Pendapatan Dan Belanja Negara, Bendahara Umum Negara. 


\section{PENDAHULUAN}

Dalam Undang-Undang Dasar 1945 Bab VIII Hal Keuangan, antara lain disebutkan bahwa anggaran pendapatan dan belanja negara ditetapkan setiap tahun dengan undangundang, dan ketentuan mengenai pajak dan pungutan lain yang bersifat memaksa untuk keperluan negara serta macam dan harga mata uang ditetapkan dengan undang-undang. Halhal lain mengenai keuangan negara sesuai dengan amanat Pasal 23C diatur dengan undang-undang.

Selama kurun waktu sejak kemerdekaan RI tahun 1945 sampai dengan tahun 2002, kelemahan perundang-undangan dalam bidang keuangan negara menjadi salah satu penyebab terjadinya beberapa bentuk penyimpangan dalam pengelolaan keuangan negara. Dalam upaya menghilangkan penyimpangan tersebut dan mewujudkan sistem pengelolaan fiskal yang berkesinambungan (sustainable) sesuai dengan aturan pokok yang telah ditetapkan dalam Undang-Undang Dasar dan asas-asas umum yang berlaku secara universal dalam penyelenggaraan pemerintahan negara diperlukan suatu undang undang yang mengatur pengelolaan keuangan negara yang tertuang dalam Undang- Undang Nomor 17 Tahun 2003 tentang Keuangan Negara (UU 17/2003).

Pengertian keuangan negara sebagaimana tercantum pada penjelasan umum Undang-Undang Keuangan Negara adalah sebagai berikut:

1. Dari sisi objek, yang dimaksud dengan keuangan negara meliputi semua hak dan kewajiban negara yang dapat dinilai dengan uang, termasuk kebijakan dan kegiatan dalam bidang fiskal, moneter, dan pengelolaan kekeayaan negara yang dipisahkan, serta segala sesuatu baik berupa uang maupun barang yang dapat dijadikan milik negara berhubung dengan pelaksanaan hak dan kewajiban tersebut.

2. Dari sisi subjek, yang dimaksud dengan keuangan negara adalah meliputi seluruh objek sebagaimana tersebut di atas yang dimiliki negara, dan/atau dikuasai oleh pemerintah pusat, pemerintah daerah, perusahaan negara/daerah, dan badan lain yang ada kaitannya dengan keuangan negara.

3. Dari sisi proses, keuangan negara mencakup seluruh rangkaian kegiatan yang berkaitan dengan pengelolaan objek sebagaimana tersebut di atas mulai dari perumusan kebijakan dan pengambilan keputusan sampai dengan pertanggungjawaban.

4. Dari sisi tujuan, keuangan negara meliputi seluruh kebijakan, kegiatan, dan hubungan hukum yang berkaitan dengan pemilikan dan/atau penguasaan objek sebagaimana tersebut di atas dalam rangka penyelenggaraan pemerintahan negara.

Selanjutnya, terkait penafsiran tentang keuangan Negara, Dian Puji Simatupang mengklasifikasikannya menjadi tiga macam, yaitu :

1. Keuangan Negara diartikan secara sempit, seperti dikemukakan oleh Harun AlRasyid, dia berpendapat bahwa yang dimaksud dengan keuangan Negara dalam Pasal 23 ayat (5) UUD 1945 sebelum perubahan adalah keuangan Negara dalam arti sempit.

2. Keuangan Negara secara luas, seperti dikemukakan oleh mantan anggota BPK Hasan Akman, bahwa dalam kaitan dengan pertanggung jawaban keuangan Negara sebagaimana dimaksud oleh Pasal 23 ayat (5) UUD 1945, maka yang dimaksud dengan Keuangan Negara adalah Keuangan Negara dalam arti luas. Jadi pertanggung jawaban Keuangan Negara yang harus dilakukan oleh pemerintah tidak saja mengenai APBN, tetapi meliput APBD, keuangan unit usaha Negara dan pada hakekatnya seluruh kekayaan Negara.

3. Dilakukan melalui pendekatan sistematik dan teleologis atau sosiologis terhadap Keuangan Negara yang dapat memberikan penafsiran yang relatif lebih akurat sesuai dengan tujuannya. Pendekatan tersebut mengandung makna Keuangan Negara didasarkan atas tujuan atau fungsi ketentuan peraturan yang bersangkutan dalam konteks masyarakat dewasa ini. Penafsiran ini paling tampak esensial dan dinamis dalam menjawab berbagai 
perkembangan yang ada dalam masyarakat.

Sesuai dengan ketentuan dalam Pasal 29 UU 17/2003, dalam rangka pengelolaan dan pertanggungjawaban Keuangan Negara yang ditetapkan dalam APBN dan APBD, perlu ditetapkan kaidah-kaidah hukum administrasi keuangan negara dan hal mengenai kaidah-kaidah hukum admnistrasi keuangan negara tersebut tertuang dalam Undang-undang Nomor 1 Tahun 2004 tentang Perbendaharaan Negara (UU 1/2004) yang dimaksudkan untuk memberikan landasan hukum di bidang administrasi keuangan negara. Dalam UU 1/2004 ini ditetapkan bahwa Perbendaharaan Negara adalah pengelolaan dan pertanggungjawaban keuangan negara, termasuk didalamnya adalah pengaturan mengenai investasi yang ditetapkan dalam APBN.

Pengertian Perbendaharaan Negara menurut Undang-Undang Nomor 1 Tahun 2004 tentang Perbendaharaan Negara (UU 1/2004) adalah "pengelolaan dan pertanggungjawaban keuangan negara, termasuk investasi dan kekayaan yang dipisahkan, yang ditetapkan dalam Anggaran Pendapatan dan Belanja Negara/Daerah, pencegahan agar jangan sampai terjadi kebocoran dan penyimpangan, pencarian sumber pembiayaan yang paling murah, dan pemanfaatan dana yang menganggur (idle cash) untuk meningkatkan nilai tambah sumber daya keuangan. Hal tersebut berdasarkan pertimbangan bahwa pada hakikatnya, negara adalah suatu lembaga politik dan dalam kedudukannya yang demikian, negara tunduk pada tatanan hukum publik. Melalui kegiatan berbagai instansi pemerintah pusat atau yang dikenal luas dengan istilah satuan kerja pemerintah pusat, negara berusaha memberikan jaminan kesejahteraan kepada rakyat (welfare state).

Menteri Keuangan selaku Bendahara Umum Negara berdasarkan ketentuan Pasal 7 ayat (2) huruf h dan Pasal 69 ayat (3) UU 1/2004, berwenang untuk menatausahakan/mengelola investasi dan melakukan pembinaan keuangan Badan Layanan Umum pemerintah pusat.

Berdasarkan ketentuan dan kewenangan Menteri Keuangan selaku Bendahara Umum Negara dalam mengelola investasi ini dideskripsikan lebih lanjut dalam Pasal 41 UU 1/2004 yang mengatur bahwa yang dimaksud investasi yang dikelola oleh Menteri Keuangan selaku Bendahara Umum Negara adalah investasi jangka panjang dalam bentuk investasi langsung, surat berharga dan saham yang selanjutnya diamanatkan untuk diatur lebih lanjut dengan Peraturan Pemerintah. Sementara itu, dalam rangka melaksanakan ketentuan Pasal 69 ayat (7) UU 1/2004 yang berkaitan dengan pengelolaan keuangan Badan Layanan Umum diterbitkan Peraturan Pemerintah Nomor 23 Tahun 2005 tentang Pengelolaan Keuangan Badan Layanan Umum sebagaimana telah diubah dengan Peraturan Pemerintah Nomor 74 Tahun 2012, yang di dalamnya juga mengatur mengenai bagaimana Badan Layanan Umum selaku satuan kerja juga dapat melakukan investasi.

Seiring dengan perkembangan perekonomian dunia, investasi merupakan instrumen penting dalam meningkatkan tingkat perekonomian dalam negeri suatu negara khususnya di Indonesia sebagai salah satu negara berkembang. Keterlibatan pemerintah pusat dalam menatausahakan investasi yang pembiayaannya bersumber dari Anggaran Pendapatan dan Belanja Negara (APBN) menjadi sangat penting, khususnya terkait dengan unit yang akan melaksanakan investasi pemerintah tersebut. Berdasarkan uraian di atas terdapat 2 (dua) pokok permasalahan yang dapat diteliti, sebagai berikut:

1. Bagaimana peraturan perundang-undangan di bidang keuangan negara dapat memberikan kepastian hukum dalam menatausahakan investasi yang dilakukan oleh Pemerintah Pusat?

2. Bagaimana harmonisasi pengaturan terahadap pelaksanaan investasi pemerintah pusat yang secara khusus dilaksanakan oleh satuan kerja Badan Layanan Umum pusat, Badan Usaha Milk Negara dan Badan Hukum Lainnya.

Tulisan ini bertujuan untuk meneliti dan mengkaji dengan harapan dapat menjawab dua pertanyaan tersebut 
1. Secara praktis, sebagaimana diatur dalam peraturan perundang-undangan dibidang keuangan negara, pelaksanaan investasi pemerintah yang merupakan investasi jangka Panjang meliputi pelaksanaan investasi dalam bentuk surat berharga, saham dan investasi langsung yang dilakukan oleh Badan Layanan Umum (BLU), Badan Usaha Milik Negara (BUMN) dan Badan Hukum Lainnya (BHL) memerlukan pengaturan yang komprehensif dan harmonis, mengingat pelaksanaan investasi pemerintah menyatukan 2 (dua) dimensi hukum yaitu antara hukum administrasi negara yang (hukum publik) dari sisi penatausahaan investasi oleh pemerintah pusat berkaitan dengan pelaksanaan investasi oleh satuan kerja Badan Layanan Umum dan hukum privat terkait dengan investasi pemerintah yang dilakukan juga oleh BUMN dan BHL. Selain itu, penelitian ini diharapkan juga dapat digunakan sebagai sumber kajian bagi masyarakat umum, termasuk bagi praktisi hukum dan akademisi.

2. Secara teoritis, hasil penelitian ini diharapkan menjadi sumbangan pemikiran terhadap pengembangan ilmu hukum dan memberikan informasi mengenai penatausahaan investasi pemerintah.

\section{Kerangka Peraturan Perundang- Undangan di Bidang Keuangan Negara Mengenai Investasi Pemerintah} investasi:

Beberapa teori dan jenis tentang

a. Teori Neo Klasik menekankan pentingnya tabungan sebagai sumber investasi. Investasi dipandang sebagai salah satu penggerak utama pertumbuhan ekonomi dan pembangunan. Makin cepat perkembangan investasi ketimbang laju pertumbuhan penduduk, makin cepat perkembangan volume stok kapital rata-rata per tenaga kerja. Makin tinggi rasio kapital per tenaga kerja cendrung makin tinggi kapasitas produksi per tenaga kerja. Tokoh Neo Klasisk, Sollow dan Swan memusatkan perhatiannya pada bagaimana pertumbuhan penduduk, akumulasi capital, kemajuan teknologi dan output saling berinteraksi dalam proses pertumbuhan ekonomi.

b. Teori Harrod-Domar mempertahankan pendapat dari para ahli ekonomi sebelumnya yang merupakan gabungan dari pendapat kaum klasik dan Keynes, beliau menekankan peranan pertumbuhan modal dalam menciptkan pertumbuhan ekonomi. Teori Harrod-Domar memandang bahwa pembentukan modal dianggap sebagai pengeluaran yang akan menambah kemampuan suatu perekonomian untuk menghasilkan barang dan atau jasa, maupun sebagai pengeluaran yang akan menambah permintaan efektif seluruh masyarakat. Dimana apabila pada suatu masa tertentu dilakukan sejumlah pembentukan modal, maka pada masa berikutnya perekonomian tersebut mempunyai kemapuan untuk menghasilkan barang-barang dan jasa yang lebih besar. Salah satu teori ekonomi pembangunan dari Harrod Domar ini adalah teori Tabungan dan Investasi yang mencapai kesimpulan terkait dengan tingginya tabungan dan investasi. Kalau tabungan dan investasi rendah maka pertumbuhan ekonomi suatu Negara juga akan rendah. Masalah pembangunan pada dasarnya merupakan masalah menambahkan investasi modal, masalah keterbelakangan adalah masalah kekurangan modal. Kalau ada modal dan modal itu diinvestasikan hasilnya adalah pembangunan ekonomi

Berdasarkan UU 17/2003, keuangan negara merupakan semua hak dan kewajiban negara yang dapat dinilai dengan uang, serta segala sesuatu baik berupa uang maupun berupa barang yang dapat dijadikan milik negara berhubung dengan pelaksanaan hak dan kewajiban tersebut. Ruang lingkup keuangan negara meliputi hak negara untuk memungut pajak, mengeluarkan dan mengedarkan uang, dan melakukan pinjaman; kewajiban negara untuk menyelenggarakan tugas layanan umum pemerintahan negara dan membayar tagihan 
pihak ketiga; penerimaan negara; pengeluaran negara; penerimaan daerah; pengeluaran daerah; kekayaan negara/kekayaan daerah yang dikelola sendiri atau oleh pihak lain berupa uang, surat berharga, piutang, barang, serta hak-hak lain yang dapat dinilai dengan uang, termasuk kekayaan yang dipisahkan pada perusahaan negara/perusahaan daerah; kekayaan pihak lain yang dikuasai oleh pemerintah dalam rangka penyelenggaraan tugas pemerintahan dan/atau kepentingan umum; kekayaan pihak lain yang diperoleh dengan menggunakan fasilitas yang diberikan pemerintah; dan kekayaan pihak lain sebagaimana dimaksud meliputi kekayaan yang dikelola oleh orang atau badan lain berdasarkan kebijakan pemerintah, yayasanyayasan di lingkungan kementerian negara/lembaga, atau perusahaan negara/daerah.

Selanjutnya dalam UU 17/2003 juga diatur mengenai kewenangan Menteri Keuangan selaku pengelola fiskal dan Bendahara Umum Negara (BUN) dalam pengelolaan keuangan negara. Kewenangan Menteri Keuangan selaku BUN juga dideskripsikan lebih lanjut dalam UU 1/2004 dalam Pasal 7 yang salah satunya adalah menempatkan uang negara dan mengelola/menatausahakan investasi. Adapun dalam Pasal 41 UU 1/2004 dideskripsikan lebih lanjut bahwa

a. Pemerintah dapat melakukan investasi jangka panjang untuk memperoleh manfaat ekonomi, sosial dan/atau manfaat lainnya.

b. Investasi sebagaimana dimaksud dilakukan dalam bentuk saham, surat utang, dan investasi langsung.

c. Investasi sebagaimana dimaksud pada ayat (1) diatur dengan peraturan pemerintah.

Dalam rangka pelaksanaan penatausahaan investasi tersebut dan guna melaksanakan amanat Pasal 41 dimaksud sejak tahun 2007 s.d tahun 2019 telah diterbitkan beberapa Peraturan Pemerintah, yaitu:

a. Peraturan Pemerintah Nomor 8 Tahun 2007 tentang Investasi Pemerintah;

b. Peraturan Pemerintah Nomor 1 Tahun 2008 tentang Investasi Pemerintah sebagaimana telah diubah dengan
Peraturan Pemerintah Nomor 49 Tahun 2011(PP 1/2008); dan

c. Peraturan Pemerintah Nomor 63 Tahun 2019 tentang Investasi Pemerintah (PP 63/2019).

Selain 3 (tiga) Peraturan Pemerintah tersebut di atas terdapat pula pengaturanpengaturan yang bersifat teknis mengenai investasi Pemerintah yang dituangkan dalam beberapa Peraturan Menteri Keuangan (PMK) sebagai pelaksanaan amanat 3 (tiga) Peraturan Pemerintah tersebut diatas dan sebagai pelaksanaan kewenangan Menteri Keuangan selaku BUN sesuai dengan UU 1/2004 dan Peraturan Pemerintah mengenai investasi pemerintah.

Berdasarkan Pasal 41 UU 1/2004 Pemerintah dalam hal ini Menteri Keuangan dalam kewenangannya selaku Bendahara Umum Negara selaku Bendahara Umum Negara melakukan investasi jangka panjang untuk memperoleh manfaat ekonomi, sosial dan/atau manfaat lainnya dalam bentuk:

a. saham,

b. surat utang; dan

c. investasi langsung.

Berdasarkan Peraturan Pemerintah Nomor 71 Tahun 2010 tentang Standar Akuntansi Pemerintahan (PP 71/2010) investasi jangka panjang dipandang dari sisi Aset merupakan Investasi jangka panjang merupakan investasi yang dimaksudkan untuk dimiliki lebih dari 12 (dua belas) bulan. Investasi tersebut yang diadakan dengan maksud untuk mendapatkan manfaat ekonomi dan manfaat sosial dalam jangka waktu lebih dari satu periode akuntansi. Investasi jangka panjang meliputi investasi nonpermanen dan permanen. Investasi nonpermanen antara lain investasi dalam Surat Utang Negara, penyertaan modal dalam proyek pembangunan, dan investasi nonpermanen lainnya. Investasi permanen antara lain penyertaan modal pemerintah dan investasi permanen lainnya.

Dalam Undang-Undang Nomor 1 Tahun 2004 tentang Perbendaharaan Negara, salah satu core business fungsi treasury adalah pengelolaan Investasi Pemerintah. Aktivitas Investasi Pemerintah dilakukan melalui 
penempatan sejumlah dana dan/ atau aset keuangan dalam bentuk saham, surat utang, dan/ atau investasi langsung, yang diharapkan dapat memberi manfaat ekonomi, sosial, dan / atau manfaat lainnya. Investasi Pemerintah yang selama ini berfokus pada penyertaan modal dari pemberian Pinjaman, secara perlahan akan difokuskan juga kepada investasi dalam bentuk surat berharga sesuai UU 1/2004. Peran Menteri Keuangan sebagai Bendahara Umum Negara yang berwenang dalam melaksanakan investasi akan dilakukan melalui operator investasi Pemerintah (OIP), baik yang berbentuk satuan kerja Badan Layanan Umum ataupun BUMN, BUMD dan/ atau badan hukum lainnya. Perluasan ruang lingkup Investasi Pemerintah baik dari sisi pelaku maupun instrumen dengan pengendalian risiko yang terukur serta fiduciary duties yang jelas perlu untuk dilakukan sehingga manfaat ekonomi, manfaat sosial, dan manfaat lainnya dapat tercapai secara optimal.

Perkembangan perekonomian dunia dan kebutuhan pengaturan yang lebih komprehensif mengenai penatausahaan investasi Pemerintah membuat Pemerintah melakukan beberapa perubahan terhadap peraturan mengenai investasi Pemerintah. Sebelum diundangkannya PP 63/2019, investasi pemeritah yang bersifat non permanen (non penyertaaan modal negara/PMN) praktis hanya dilakukan Pusat Investasi Pemeritah sebagai satuan kerja (satker) yang menerapkan pengelolaan keuangan Badan Layanan Umum (BLU). Kewenangan Menteri Keuangan selaku BUN dalam UU 1/2004 dan PP 1/2008 diejawantahkan dalam pengelolaan investasi yang hanya dilakukan oleh PIP selaku BLU dibawah pembinaan teknis dan administratif oleh Menteri Keuangan yang dalam hal ini pembinaan tersebut dilakukan oleh unit eselon 1 di Kementerian Keuangan yaitu Sekretariat Jenderal dan Direktorat Jenderal Perbendaharaan. Dengan memperhatikan perkembangan kondisi dan kebijakan Pemerintah dalam bidan investasi dan untuk meningkatkan efektivitas pengelolaan investasi Pemerintah, PP 1/2008 telah digantikan dengan diundangkannya PP 63/2019.

PP 1/2008 mengatur bahwa titik berat investasi berada pada sektor infrastruktur selain investasi dalam bentuk surat berharga. Sedangkan sektor lainnya dapat dilakukan dengan terlebih dahulu memerlukan persetujuan Menteri. Sesuai mandat yang diatur dalam PP 1/2008, investasi langsung dilakukan melalui penyertaan modal dan pemberian Pinjaman dan dapat dilakukan dengan skema kerja sama Pemerintah dan Badan Usaha.

PP 63/2019 diterbitkan untuk menjawab kebutuhan pelaksanaan investasi pemerintah pusat yang lebih optimal dimasa yang akan datang, sehingga perlu untuk dilakukan penyempurnaan pengaturan mengenai kewenangan pengelolaan investasi Pemerintah yang meliputi:

a. kewenangan regulasi:

b. kewenangan supervisi; dan

c. kewenangan operasional.

Pembagian 3 (tiga) kewenangan ini merupakan ekosistem ideal untuk pengelolaan investasi pemerintah pusat berdasarkan best practices pengelolaan investasi dari beberapa negara. Dengan demikian, pembagian kewenangan dalam pengelolaan investasi pemerintah pusat tersebut akan meningkatkan akuntabilitas dan menjamin terselenggaranya saling uji (check and balances) dalam proses pelaksanaan investasi mulai dari tahap perencanaan, pelaksanaan, dan pertanggungjwaban.

Selanjutnya, sebagai pengaturan teknis sebagai pelaksanaan amanat Pasal 16, Pasal 21, Pasal 27, Pasal 37, Pasal 39, Pasal43, Pasal 44, Pasal 48, Pasal 52, dan Pasal 53 PP 63/2019 dan dalam rangka menjalankan kewenangan Menteri Keuangan selaku BUN telah diterbikan Peraturan Menteri Keuangan Nomor 53 Tahun 2020 tentang Tata Cara Investasi Pemerintah (PMK 53/2020)

Sementara itu, sebagaimana diketahui bahwa jenis investasi berdasarkan jangka waktu investasi tidak terbatas hanya investasi jangka panjang yang telah terakomodir dalam 
PP 63/2019 dan PMK 53/2020, namun juga terdapat investasi lain yaitu investasi jangka pendek yang berdasarkan ketentuan dalam Pernyataan Standar Akuntansi Pemerintahan (PSAP) 06 tentang Investasi yang tertuang dalam PP 71/2010, investasi jangka pendek adalah investasi yang dapat segera dicairkan dan dimaksudkan untuk dimiliki selama 12 (dua belas) bulan atau kurang. Dalam rezim UU $1 / 2004$, istilah investasi jangka pendek tidak diatur namun berdasarkan PP 71/2010 dalam perlakuan akuntansi, investasi jangka pendek ditempatkan pada PSAP.06 dan diakui sebagai bagian dari manajemen kas. Hal terkait dengan manajemen kas sendiri terakomodir dalam salahs satu kewenangan Menteri Keuangan selaku Bendahara Umum Negara dalam kaitannya dengan pelaksanaan pengelolaan kas.

Selanjutnya, dalam rangka pengelolaan kas sendiri, telah diterbitkan Peraturan Pemerintah Nomor 39 Tahun 2007 tentang Pengelolaan Uang Negara/Daerah (PP 39/2007) sebagai pelaksanaan amanat ketentuan Pasal 28 ayat (1) UU 1/2004 yang selanjutnya terkait dengan pengelolaan uang negara yang dilakukan oleh Menteri Keuangan telah diterbitkan beberapa Peraturan Menteri Keuangan (PMK) yang salah satunya adalah PMK Nomor 03 Tahun 2010 tentang Pengelolaan Kelebihan dan Kekurangan Kas sebagaimana telah diubah dengan PMK Nomor 115 Tahun 2016. Namun demikian, terkait dengan investasi jangka pendek yang diakui sebagai pelaksanaan manajemen kas ini belum terdapat pengaturan yang lebih teknis dan lebih actual sebagaimana pengaturan dalam rangka meregulasi pelaksanaan investasi jangka panjang yang dilakukan oleh Pemerintah pusat. Hal tersebut dapat terlihat dari PP yang mengatur pengelolaan uang negara/daerah yang masih belum dilakukan updating/perubahan yang seharusnya untuk mengakomodir perkembangan investasi sebagai instrumen yang sangat penting dalam pembangunan ekonomi negara Indonesia sebagai negara yang sedang berkembang.

\section{Harmonisasi Pengaturan Pelaksanaan Investasi Pemerintah.}

Dalam UU 1/2004 jo. PP 63 Tahun 2019 diatur bahwa investasi Pemerintah non permanen dilakukan oleh Pemerintah dalam bentuk:

a. Saham yang merupakan saham yang tercatat dan/atau diperdagangkan di bursa efek dan saham yang tidak tercatat dan/atau tidak diperdagangkan di bursa efek sesuai dengan ketentuan peraturan perundang- undangan

b. Surat berharga berupa surat utang dan sukuk yang diterbitkan oleh:

- Pemerintah pusat dan Pemerintah Daerah

- Korporasi dan/atau BHL

- Pemerintah negara lain; dan

- Korporasi dan/atau badan hukum asing.

c. Investasi langsung dalam bentuk:

- Pemberian pinjaman

- Kerjasama investasi; dan

- Investasi langsung lainnya

Bentuk-bentuk investasi tersebut dilakukan Operator Investasi Pemerintah (OIP) yang dilaksanakan oleh BLU, BUMN dan/atau BHL yang ditunjuk atau ditetapkan oleh Menteri Keuangan selaku BUN. Adapun Sumber Investasi Pemerintah berasal dari:
a. APBN;
b. imbal hasil;
c. pendapatan dari layanan/usaha;
d. hibah; dan/ atau
e. sumber lain yang sah.

Kewenangan operasional OIP yang dilaksanakan oleh BUMN dan/ atau BHL sebagaimana dimaksud dalam Pasal 18 dilakukan berdasarkan Perjanjian Investasi yang berisikan hal-hal sebagai berikut:

a. hak dan kewajiban para pihak;

b. rencana kerja pengelolaan Investasi Pemerintah;

c. penempatan dana dan/ atau aset keuangan untuk pelaksanaan Investasi Pemerintah;

d. pengendalian risiko atas pengelolaan Investasi Pemerintah;

e. tindakan yang diperlukan dalam ha1 terjadi sengketa atau perselisihan dalam pelaksanaan Investasi Pemerintah;

f. pelaksanaan Divestasi atas 
Investasi Pemerintah termasuk Divestasi yang ditentukan oleh Menteri sesuai ketentuan peraturan perundang-undangan;

g. penyampaian laporan pengelolaan Investasi Pemerintah;

h. pengawasan atas pelaksanaan Investasi Pemerintah yang dilakukannya;

i. berakhirnya Perjanjian Investasi;

j. penyelesaian sengketa; dan

$\mathrm{k}$. penyampaian tata kelola investasi yang berlaku.

Berbeda dengan pelaksanaan investasi pemerintah yang dijalankan oleh BLU yaitu dengan penunjukan dari Menteri Keuangan, pelaksanaan investasi yang dijalankan oleh BUMN dan BHL sebagai badan hukum privat dilaksanakan berdasarkan perjanjian antara Menteri Keuangan dan Direktur Utama/pimpinan tertinggi dari BUMN dan/atau BHL tersebut sebagai operator investasi Pemerintah.

Dalam PP 63/2019 dan PMK $53 / 2020$ juga diatur mengenai pelaksanaan investasi oleh BUMN dan BHL yang dijalankan berdasarkan peraturan perundang-undangan yang mengatur mengenai BUMN dan Perseroan Terbatas. Namun demikian terdapat beberapa pengaturan mengenai supervisi dari Menteri Keuangan selaku BUN terhadap pelaksanaan investasi yang dijalankan oleh BLU, BUMN dan BHL tersebut mengingat sumber pendanaan dari pembiayaan investasi tersebut dialokasikan pada APBN yang berada dalam pengelolaan Menteri Keuangan selaku BUN dan sebagai Komite Investasi Pemerintah.

Sementara itu, pengaturan mengenai investasi pemerintah yang dilakukan BLU selama ini dijalankan berdasarkan Peraturan Pemerintah Nomor 23 Tahun 2005 tentang Pengelolaan Keuangan Badan Layanan Umum sebagaimana telah diubah dengan Peraturan Pemerintah Nomor 74 Tahun 2012 (PP 23/2005). Pengaturan dalam PP tersebut juga telah ditindaklanjuti dengan pengaturan teknisnya dalam PMK Nomor 129 Tahun 2020 tentang Pedoman Pengelolaan Badan Layanan Umum (PMK 129/2020).

Terdapat hal yang menarik dari sudut pandang hukum terkait dengan pelaksanaan investasi pemerintah pusat yang dilakukan oleh:

- BLU, dengan rezim pengeloalaan keuangna BLUnya,

- BUMN dan BHL sebagai entitas privat (non public entity), yang antara lain tunduk pada peraturan perundangundangan di bidang Perseroan Terbatas, BUMN dan pengaturan sektoral terkait BHL.

Pengaturan investasi yang dilakukan BLU berdasarkan PP 23/2005 dan PMK 129/2010 mengenal BLU sebagai investor (yang memiliki modal) bukan hanya sebagai institusi yang diberikan penugasan oleh Pemerintah pusat sebagai operator investasi pemerintah untuk melaksanakan investasi jangka panjang non permanen. Hal ini sebenarnya telah diakomodir dalam ketentuan mengenai penempatan dana oleh BLU yang diatur dalam Pasal 88 PMK 53/2020 yang mengakomodir semangat dari PMK 129/2020 yang memperbolehkan BLU untuk berinvestasi dengan menggunakan sumber dana dari hasil kelolaan BLU yang disinyalir banyak yang berbentuk idle cash.

Pengaturan investasi yang dilakukan oleh BUMN dan BHL sebagai private entity pun telah terakomodir dalam PP 63/2020 maupun PMK 53/2020 dengan tujuan agar pemanfaatan dana APBN dapat terlaksana secara efektif dengan menggunakan institusi yang telah well-capable dalam menatausahakan investasi.

Namun demikian, irisan-irisan hukum terkait pengaturan investasi yang dilaksanakan oleh BLU, BUMN maupun BHL seiring perkembangan ekonomi dunia dan nasional sesuai denga tujuan politik kepemimpinan negara, haruslah dijawab dengan penyesuaian peraturan perundang-undangan terkait sehingga tidak ada tumpang tindih pengaturan atau bahkan kesimpangsiuran pengaturan yang dapat menyebabkan lambatnya perkembangan ekonomi di Indonesia. 


\section{KESIMPULAN}

a. Pengaturan mengenai investasi pemerintah pusat yang bersifat non permanen merupakan jawaban atas kebutuhan pengaturan yang komprehensif terhadap kebutuhan akan adanya efektivitas penggunaan keuangan negara yang bersumber dari APBN. Pengaturan mengenai investasi pemerintah yang saat ini dituangkan dalam PP 63/2019 dan PMK 53/2020 merupakan pengaturan yang telah diharmonisasikan dengan seluruh pengaturan pada sector privat dengan diaturnya pelaksanaan investasi pemerintah yang dilaksanakan oleh BUMN dan BHL yang tertuang dalam perjanjian dan dilaksanakan dengan peraturan perundang-undangan terkait.

b. Terkait dengan investasi jangka pendek yang diakui sebagai pelaksanaan manajemen kas ini belum terdapat pengaturan yang lebih teknis dan lebih actual sebagaimana pengaturan dalam rangka meregulasi pelaksanaan investasi jangka panjang yang dilakukan oleh Pemerintah pusat. Hal tersebut dapat terlihat dari PP yang mengatur pengelolaan uang negara/daerah yang masih belum dilakukan updating/perubahan yang seharusnya untuk mengakomodir perkembangan investasi sebagai instrumen yang sangat penting dalam pembangunan ekonomi negara Indonesia sebagai negara yang sedang berkembang.

c. irisan-irisan hukum terkait pengaturan investasi yang dilaksanakan oleh BLU, BUMN maupun BHL seiring perkembangan ekonomi dunia dan nasional sesuai denga tujuan politik kepemimpinan negara, haruslah dijawab dengan penyesuaian peraturan perundangundangan terkait sehingga tidak ada tumpang tindih pengaturan atau bahkan kesimpangsiuran pengaturan yang dapat menyebabkan lambatnya perkembangan ekonomi di Indonesia.

\section{DAFTAR PUSTAKA}

\section{Buku}

Atmadja, Arifin P Soeria. Keuangan Publik dalam Prespektif Hukum-Praktik dan
Kritik, Depok: Fakultas Hukum UI, 2005

Arifin Soeriaatmadja, "Laporan Akhir Kopendium Bidang Hukum Keuangan Negara (Sumber-sumber Keuangan Negara)", (BPHN Kementerian Hukum dan Hak Asasi Manusia: Jakarta, 2010).

Adrian Sutedi, Hukum Keuangan Negara, (Jakarta: Sinar Grafika), 2010.

Dian Puji N. Simatupang, "Determinasi Kebijakan Anggaran Negara" (Jakarta : Papas Sinar Sinanti, 2005)

Muhamad Djafar Saidi, "Hukum Keuangan Negara (Edisi ke-3)", (Jakarta: Rajawali Pers, 2014)

\section{Peraturan Perundang-undangan}

Indonesia. Undang-Undang Keuangan Negara, UU No. 17 Tahun 2003, LN Tahun 2003, TLN No. 4286.

Undang-Undang Perbendaharaan Negara, UU No. 1 Tahun 2004, LN No. 5 Tahun 2004, TLN No. 4355. 